\title{
Predictors of Positive Subxiphoid Pericardial Window in Stable Patients with Penetrating Injuries to the Precordial Region
}

\author{
1Álvaro I Sánchez, ${ }^{2}$ Alberto F García, ${ }^{3}$ Mauricio Velsquez, ${ }^{4}$ Juan Carlos Puyana
}

\begin{abstract}
Background: Subxiphoid pericardial window (SPW) remains a valuable diagnostic tool for patients at risk of occult cardiac injuries. However, how to select patients that could benefit from this procedure remains unclear. We aimed to identify clinical predictors of positive SPW in patients with penetrating precordial injuries.
\end{abstract}

Materials and methods: Prospective data collection of 183 patients who underwent SPW for the exclusion of penetrating cardiac injuries during $2002-2004$ at a level I trauma centre in Cali, Colombia. Patient's demographics, clinical characteristics, and injury information were obtained. Independent predictors of positive SPW were assessed using stepwise logistic regressions.

Results: There were 41 positive SPW (22.4\%). Unadjusted analyses demonstrated that stab/knife wounds (OR 2.48, 95\% $\mathrm{Cl} 1.17-5.25, \mathrm{p}=0.017$ ), single wound (OR 14.61, 95\% Cl $1.9-110, p=0.009$ ), and clinical signs of pericardiac tamponade (OR 8.52, 95\% Cl 3.92-18.4, $\mathrm{p}<0.001$ ) were associated with increased odds of positive SPW. Conversely, systolic blood pressure $(0.98,95 \% \mathrm{Cl} 0.96-0.99)$ and stable physiological index (OR 0.31, 95\% Cl 0.14-0.65, $\mathrm{p}=0.002$ ) were associated with decreased odds. In multivariable analyses, signs of pericardiac tamponade (OR 6.37, 95\% Cl 2.78-14.6, $\mathrm{p}<0.001$ ), and single injuries (OR 12.99, 95\% Cl 1.6-102.7, $\mathrm{p}=0.015$ ) remained as independent predictors of positive SPW.

\footnotetext{
${ }^{1}$ Surgical Resident, ${ }^{2}$ Associate Professor, ${ }^{3}$ Thoracic Surgeon, ${ }^{4}$ Associate Professor

${ }^{1}$ Universidad CES - Fundación Valle del Lili, Carrera 98 No. 18-49, Cali, Colombia

${ }^{2}$ Department of Surgery, Universidad del Valle, Calle 5 No. 36-08, 4th floor, Cali, Colombia. Research Associate, CISALVA Institute, Universidad del Valle, Calle 4B No. 36-00, Edificio 100, Oficina 114, Cali, Colombia. Trauma and Acute Care Surgeon, Department of Surgery, Fundación Valle del Lili, Carrera 98 No. 18-49, Cali, Colombia

${ }^{3}$ Department of Surgery, Fundación Valle del Lili, Carrera 98 No. 18-49, Cali, Colombia

${ }^{4}$ Department of Surgery, University of Pittsburgh Medical Center, Pittsburgh, Pennsylvania, USA

Corresponding Author: Alberto F García, Department of Surgery, Carrera 98 \# 18-49, Fundación Valle del Lili, Cali Colombia, Phone: +57(2)3319090, e-mail: afgm2011@gmail. com
}

Conclusion: Emphasis on early recognition of the clinical signs of pericardiac tamponade could be the most important factor for the identification of occult cardiac injuries. Patients with multiple wounds to the precordial region who reached the hospital may not benefit from a SPW. However, high level of awareness is important because the incidence of occult cardiac injuries is not negligible.

Keywords: Cardiac tamponade, Penetrating cardiac injury, Precordial region, Subxiphoid pericardial window.

How to cite this article: Sánchez Ál, García AF, Velásquez M, Puyana JC. Predictors of Positive Subxiphoid Pericardial Window in Stable Patients with Penetrating Injuries to the Precordial Region. Panam J Trauma Crit Care Emerg Surg 2015;4(3):43-51.

\section{Source of support: Nil}

Conflict of interest: None declared

\section{RESUMEN}

Antecedentes: La ventana pericárdica subxifoidea (SPW) sigue siendo una valiosa herramienta de diagnóstico para los pacientes con riesgo de lesiones cardíacas ocultas. Sin embargo, la forma de seleccionar a los pacientes que podrían beneficiarse de este procedimiento sigue siendo poco clara. El objetivo fue identificar predictores clínicos de SPW positivos en pacientes con lesiones penetrantes precordiales.

Materiales y métodos: Recolección de datos prospectivos de 183 pacientes a los que se le realizo SPW para la exclusión de lesiones cardiacas penetrantes durante el 2002 hasta 2004 en un centro de trauma de nivel I en Cali, Colombia. Se obtuvo datos demográficos del paciente, características clínicas y la lesión. Los predictores independientes de SPW positivo se evaluaron mediante regresión logística paso a paso.

Resultados: Hubo 41 positivos para SPW (22,4\%). Análisis no ajustados demostraron que las heridas de arma blanca/ cuchillo (OR 2.48, IC 95\%: 1,17 a 5,25; $p=0,017$ ), sola herida (OR 14,61; IC del 95\%: 1,9 a 110, p =0,009), y los signos clínicos de taponamiento pericárdico (OR 8,52, IC 95\% 3,92 a 18,4, $p<0,001$ ) se asociaron con mayores probabilidades de un SPW positivo. Por el contrario, la presión arterial sistólica (Cl 0,98, 95\%: 0,96 a 0,99) y el índice fisiológico estable (OR 0,31; IC del 95\%: 0,14 a 0,65; $p=0,002$ ) se asociaron con una disminución de las probabilidades. En el análisis multivariable, los signos de taponamiento pericárdico (OR 6,37; IC del 95\%: 2,78 a 14,6, p<0,001), y lesiones individuales (OR 12,99, 95\% Cl 1,6 a $102,7, p=0,015)$ permanecieron como predictores independientes del SPW positivo.

Presented in the Resident Paper Competition at the Panamerican Trauma Society Congress, Panama City, Panama in November 2014 
Conclusión: El énfasis en el reconocimiento temprano de los signos clínicos de taponamiento pericárdico podría ser el factor más importante para la identificación de las lesiones cardíacas ocultas. Los pacientes con múltiples heridas en la región del pecho que llegaron al hospital no se pueden beneficiar de un SPW. Sin embargo, un alto nivel de conciencia es importante porque la incidencia de las lesiones cardíacas ocultas no es despreciable.

Palabras clave: Lesión penetrante cardiaca, Región del precordio, Taponamiento cardíaco, Ventana pericárdica subxifoidea.

\section{INTRODUCTION}

Penetrating cardiac trauma is a highly lethal injury, with relatively few victims surviving long enough to reach the hospital with signs of life, even with improvements in organized emergency medical transport systems. ${ }^{1,2}$ More frustrating, is the fact that mortality has not changed much, even in major trauma centre in the United States (US) over what period of time. ${ }^{3}$ Rapid bleeding into the pericardium favors clotting and as pericardial fluid accumulates, a decrease in ventricular filling occurs, leading to a decrease in stroke volume, consequently leading to compensatory tachycardia and increased right heart filling pressures. The limits of right-sided distensibility are reached as the pericardium fills with blood, and the septum shifts toward the left side, further compromising left ventricular function and producing the clinical picture of tamponade. However, patients with penetrating cardiac injury can present with a clinical spectrum from full cardiac arrest to asymptomatic with normal vital signs. ${ }^{2}$ Decisions to aggressively intervene are made more easily in the patients with obvious circulatory collapse upon arrival to the emergency department (ER). Nevertheless, two thirds of the patients could present with transient or no signs of hemodynamic instability. ${ }^{4}$

The diagnosis of hemopericardium can be made by ultrasonography of the pericardial sac, but the exam is highly dependent on the operator skills, it has a highly sensitivity and specificity, and the presence of associated hemothorax can significantly increase false negative reports..$^{5}$ A subxiphoid pericardial window (SPW) is a useful intervention when there is a possible occult cardiac injury. The sensitivity and specificity are near 100 and $92 \%$, respectively. The procedure is quick, simple, and easy to perform. However, it is invasive and the magnitude and true incidence of its complications have not been completely defined. ${ }^{6}$ There has been a significant controversy in the past with regards to its indications. To our knowledge, how to select patients that could benefit from this procedure remains unclear. ${ }^{2}$ Therefore, the aim of this study was to identify clinical predictors of positive
SPW in stable patients with penetrating injuries to the precordial region.

\section{MATERIALS AND METHODS}

This prospective observational study took place during 2000 - 2004 at an urban level I trauma centre in Cali, Colombia, a city characterized by a high incidence of interpersonal violence. ${ }^{7}$ Injured patients admitted to the emergency department were assessed initially with the advanced trauma life support (ATLS) protocols. ${ }^{8}$ Patients with penetrating injuries to the precordial region were selected. Penetrating injuries to the precordial region were defined as a stab/knife or firearm wounds inferiorly to the clavicles, superiorly to the costal margins, and medial to the mid clavicle lines. In addition, patients with thoracoabdominal firearm wounds with bullet tracts suspected to be in close proximity to the heart were also included. Patients with obvious cardiac injuries presenting with hemorrhagic shock, with pulseless electrical activity, or with cardiac arrest witnessed by medical personnel but still with signs of life were immediately transferred to the immediately adjacent operating room (OR) for emergency or resuscitative thoracotomy as necessary and were excluded from the study. Patients with drainage of $>1.51$ of blood after chest tube placement or $>200 \mathrm{ml}$ per hour of blood from thoracostomy were also transferred to the OR for emergency/urgent thoracotomy and were also excluded.

Patients with hemodynamic stability, who had no other indication of thoracotomy, but with a high suspicion for occult cardiac injuries, were taken to the OR for SPW. In a supine position under general anesthesia, an 8 to $10 \mathrm{~cm}$ incision was made in the midline over the xiphoid process through the skin and subcutaneous tissue, achieving hemostasis by electrocautery. The xiphoid process was dissected and displaced cephalic and the adipose tissue beneath the xiphoid was separated with blunt dissection until, by digital palpation of the transmitted cardiac impulse, the pericardium was localized. When hemodynamic status allowed, patients were placed in a reverse Trendelenburg position to allow the pericardium to descend and become more accessible. The pericardium was firmly grasped and the surgical area cleared with normal saline to remove blood, to reduce the likelihood of a false positive result. A longitudinal incision of approximately $1 \mathrm{~cm}$ was made in the pericardium, meticulously avoiding laceration of the underlying epicardium. The characteristic of the effluent was observed. When necessary, suction catheters were passed into the incision to liberate clots and to allow blood to escape through the aperture. ${ }^{9}$ Patients in whom the cardiac wound was discarded by other method were also excluded. 
Patients' demographics, injury mechanism, and clinical findings were recorded at emergency department. Physiologic alterations accompany the injured heart and serve to stratify the group of patients that could benefit from resuscitative thoracotomy; therefore, patients were stratified according to the physiological index (PI) described by Ivatury et $\mathrm{al}^{10}$ based on the degree of transient physiologic deterioration. The PI was calculated from patients' clinical status on admission.

Beck's triad (low systolic blood pressure (SBP), raised venous pressure, muffled cardiac sounds) and Kussmaul's sign (jugular venous distention on inspiration) are classic presentations of pericardial tamponade; any of these clinical signs on admission were recorded. Information regarding the surgical intervention, type and characteristics of the procedures, surgical findings, and anatomic description of injuries were obtained from the operative reports. Main outcome measure was whether the SPW was positive or not. A positive SPW was defined as the presence of blood in the pericardial sac in the form of active bleeding, blood clots, or blood staining of the pericardial fluid.

Variables were analyzed descriptively by the presence of outcome. Qualitative variables were summarized using relative and absolute frequencies and comparisons were performed using Chi-squared or fisher's exact tests. Continuous variables were summarized using means, standard deviations (SD), medians, and inter quartile ranges (IQR) and comparisons were performed using nonparametric tests given their non-normal distributions. To obtain a basic idea of the association of predictors for positive SPW, simple logistic regressions were performed, calculating odds ratios (OR), $95 \%$ confidence intervals (CI), and p-values. Full assessment of predictors independently associated with a positive SPW was conducted using multivariable logistic regressions and likelihood ratio tests in a step-wise manner, removing variables if the associated regression coefficient had a $\mathrm{p}$-value greater than 0.1 . Quality of the final prognostic model was assessed in terms of calibration by the Hosmer-Lemeshow goodness-of-fit (GOF) test and in terms of discrimination with the area under the receiver operation characteristic curve (AUC). The accuracy of SPW for the diagnosis of cardiac injuries was presented in terms of sensibility, specificity, likelihood ratios and predictive values.

\section{RESULTS}

During the study period, 287 patients with penetrating injuries to the precordial region or within close proximity to the heart were seen in the emergency department. There were 104 exclusions: eight deaths on admission, 68 emergency/urgent thoracotomies, and 28 cardiac wounds discarded by other methods.

A total of 183 hemodynamically stable patients with penetrating trauma to thoracic box were taken to the OR for SPW; $176(96.2 \%)$ were males. Median age was 25 years (IQR 20-32). Injury mechanism occurred in 99 (54.1\%) patients with stab/knife and in $84(45.9 \%)$ with firearms. Single wound injuries to the precordial region were observed in 131 (71.6\%) patients; whereas single injuries in other location were observed in 13 (7.1\%) patients; multiple injuries to the precordial region were observed in $39(21.3 \%)$ patients. Median SBP on admission was $80 \mathrm{~mm} \mathrm{Hg}$ (IQR 80-110). Clinical status on admission given by the PI was stable in 93 (50.8\%) patients; there were $79(43.2 \%)$ patients in whom SBP were $<80 \mathrm{~mm} \mathrm{Hg}$ but conscious and there were $11(6.0 \%)$ patients at emergency department with treaty pulse, no measureable BP, and semiconscious. Any sign of pericardial tamponade was present on admission in $47(25.7 \%)$ patients (Table 1 ).

There were 41 positive SPW (22.4\%); all were males with median age of 24 (IQR, 20-29). A simple logistic regression indicated no statistically significant increased odds of positive SPW with increased age (OR 0.98, 95\% CI $0.95-1.01, \mathrm{p}=0.382$ ). The proportion of positive SPW in patients injured with stab/knife and firearms were $29.3 \%$ (29 patients) and 14.3\% (12 patients), respectively. The odds of positive SPW among stab/knife wounds were significantly higher than among firearms (OR 2.48, 95\% CI $1.17-5.25, \mathrm{p}=0.017)$. The proportions of positive SPW in patients with single precordial injuries and single injuries in other locations were $27.5 \%$ (36 patients) and $30.8 \%$ (four patients), respectively; combining those patients with single injuries the proportion of positive SPW was $27.8 \%$ (40 patients). The proportion of positive SPW in patients with multiple injuries was $2.6 \%$ (only 1 patient). The odds of positive SPW in patients with single injuries were significantly higher than in patients with multiple injuries (OR 14.61, 95\% CI 1.9-110.0, p = 0.009). Median SBP in patients with positive and negative SPW were $80 \mathrm{~mm} \mathrm{Hg}$ (IQR 70-85) and $95 \mathrm{~mm} \mathrm{Hg}$ (IQR 80-110), respectively. The odds of positive SPW decreased significantly with increased SBP (OR 0.98, 95\% CI 0.96-0.99, $\mathrm{p}=0.005$ ). The proportion of positive SPW was $12.9 \%$ (12 patients) among stable PI patients, $34.2 \%$ (27 patients) among patients with SBP $<80 \mathrm{~mm} \mathrm{Hg}$ and conscious, and $18.2 \%$ (two patients) among patients with treaty pulse, no measurable $\mathrm{BP}$, and semiconscious. The odds of positive SPW in patients with stable PI were significantly lower than in a combined group of patients with instable PI (OR 0.31, $95 \%$ CI $0.14-0.65, \mathrm{p}=0.002$ ). The proportion of positive SPW in patients with and without cardiac tamponade on admission was $53.2 \%$ (25 patients) and $11.8 \%$ (16 patients), 
respectively. The simple logistic regression indicated that the odds of positive SPW were higher when classic signs of pericardial tamponade were present (OR 8.52, 95\% CI 3.92-18.4, $\mathrm{p}<0.001$ ) (Tables 1 and 2).

A multivariable logistic regression model was created in order to identify predictors independently associated with a positive SPW. Initially, predictors significantly associated with positive SPW in simple logistic regressions were included: stab/knife mechanism, single injury, SBP, stable PI, and any sing of pericardial tamponade. Using a stepwise manner, those variables with a p-value $<0.1$ were retained in the final model. The final stepwise multivariable logistic regression indicated that single injury (OR 12.99, 95\% CI 1.6-102.7, p = 0.015) and any clinical sign of pericardial tamponade (OR 6.37, 95\% CI 2.78-14.6, p < 0.001) were independently associated with positive SPW. Systolic blood pressure was not statistically associated with a positive systolic blood pressure (OR 0.98, 95\% CI 0.97-1.00, p = 0.087) (Table 2). Additional analyses indicated that the odds of a positive SPW in patients with a single injury in other location was higher than in patients with a single injury in the precordial region, however, this difference did not reach statistical significance (OR 2.98, 95\% CI 0.76-11.60, $\mathrm{p}=0.115$ ). The

Table 1: Characteristics of hemodynamic stable patients with penetrating injuries to the precordial region who underwent a SPW

\begin{tabular}{|c|c|c|c|}
\hline Characteristics & $\begin{array}{l}\text { Total of patients } \\
(n=183)\end{array}$ & Positive SPW & $p$-value \\
\hline \multicolumn{4}{|l|}{ Age (years) } \\
\hline Mean (SD) & $27.8(11.4)$ & $26.4(10.5)$ & 0.390 \\
\hline Median (IQR) & $25(20-32)$ & $24(20-29)$ & \\
\hline \multicolumn{4}{|l|}{ Sex } \\
\hline Males, n (\%) & $176(96.2)$ & $41(23.3)$ & 0.352 \\
\hline Females, n (\%) & $7(3.8)$ & $0(0.0)$ & \\
\hline \multicolumn{4}{|l|}{ Mechanism } \\
\hline Stab/knife, n (\%) & $99(54.1)$ & $29(29.3)$ & 0.015 \\
\hline Firearm, n (\%) & $84(45.9)$ & $12(14.3)$ & \\
\hline \multicolumn{4}{|l|}{ Number and location of injuries } \\
\hline Single precordial injury, $\mathrm{n}(\%)$ & $131(71.6)$ & $36(27.5)$ & 0.001 \\
\hline Single injury in other location, $\mathrm{n}(\%)$ & $13(7.1)$ & $4(30.8)$ & \\
\hline Multiple injuries, n (\%) & $39(21.3)$ & $1(2.6)$ & \\
\hline \multicolumn{4}{|l|}{ Systolic BP } \\
\hline Mean (SD) & $91.0(28.4)$ & $79.5(25.6)$ & 0.002 \\
\hline Median (IQR) & $80(80-110)$ & $80(70-85)$ & \\
\hline \multicolumn{4}{|l|}{ Physiological index } \\
\hline Stable, n (\%) & $93(50.8)$ & $12(12.9)$ & 0.003 \\
\hline Systolic $\mathrm{BP}<80 \mathrm{~mm} \mathrm{Hg}$ and conscious, $\mathrm{n}(\%)$ & $79(43.2)$ & $27(34.2)$ & \\
\hline Thready pulse, no measurable BP, and semiconscious, $\mathrm{n}(\%)$ & $11(6.0)$ & $2(18.2)$ & \\
\hline \multicolumn{4}{|l|}{ Pericardial tamponade } \\
\hline Yes, n (\%) & $47(25.7)$ & $25(53.2)$ & $<0.001$ \\
\hline No, $n(\%)$ & $136(74.3)$ & $16(11.8)$ & \\
\hline \multicolumn{4}{|l|}{$S P W$} \\
\hline Positive, n (\%) & $41(22.4)$ & - & - \\
\hline
\end{tabular}

SPW: subxiphoid pericardial window; SD: standard deviation; IQR: interquartile range; BP: blood pressure.

Ellipses indicate not applicable

Table 2: Predictors associated with a positive SPW in hemodynamic stable patients with penetrating injuries to the precordial region who underwent a SPW

\begin{tabular}{|c|c|c|c|c|}
\hline & \multicolumn{2}{|c|}{ Unadjusted analysis $^{a}$} & \multicolumn{2}{|c|}{ Adjusted analysis ${ }^{b}$} \\
\hline & OR $(95 \% \mathrm{Cl})$ & $p$-value & OR $(95 \% \mathrm{Cl})$ & $p$-value \\
\hline Stab/knife mechanism & $2.48(1.17-5.25)$ & 0.017 & - & 0.325 \\
\hline Single injuries & $14.61(1.9-110.0)$ & 0.009 & $12.99(1.6-102.7)$ & 0.015 \\
\hline Systolic BP & $0.98(0.96-0.99)$ & 0.005 & $0.98(0.97-1.00)$ & 0.087 \\
\hline Stable PI & $0.31(0.14-0.65)$ & 0.002 & - & 0.642 \\
\hline Pericardial tamponade & $8.52(3.92-18.4)$ & $<0.001$ & $6.37(2.78-14.6)$ & $<0.001$ \\
\hline
\end{tabular}

SPW: Subxiphoid pericardial window; BP: blood pressure; PI: physiological index; OR: odds ratio; Cl: confidence interval a Simple logistic regression.

bStepwise multivariable logistic regression model with backwards elimination, controlled for mechanism, number of injuries, systolic BP, $\mathrm{PI}$, and pericardiac tamponade. Variables with $\mathrm{p}$-value $<0.1$ were retained in the model.

Ellipses indicate not applicable 
final regression model demonstrated adequate calibration ( $\mathrm{p}=0.659)$ and acceptable-to-excellent discrimination (AUC 0.817, 95\% CI 0.747-0.886).

In patients with positive SPW, thoracotomy was performed in 40 (97.6\%): cardiac injuries were found in 33, intrapericardial great vessel injuries in one, pericardial without cardiac or great vessel injuries in five, and lung injuries in one; thoracotomy was not performed in one (2.4\%) patient. In patients with negative SPW, thoracotomy was performed in 45 (31.7\%): cardiac injuries were found in one patient, lung injuries in 36 , and other thoracic injuries in 8; thoracotomy was not performed in 97 (68.3\%) patients. The sensibility and specificity of SPW for the diagnosis of cardiac injuries were 97.1 and $94.6 \%$, the positive and negative likelihood ratios were 18.07 and 0.03 , and the positive and negative predictive values were 80.5 and $99.3 \%$, respectively.

\section{DISCUSSION}

In this study, 183 hemodynamic stable patients with penetrating injuries to the precordial region underwent SPW during a 3 years period. Stab/knife wounds, single injury, and the presence of any sign of pericardial tamponade were associated with higher rates of positive SPW. Conversely, SBP and stable PI were associated with lower rates of positive SPW. However, in the final multivariable logistic regression model, SBP and stable PI were not associated with positive SPW, whereas signs of pericardial tamponade and single injury were the only two independent predictors associated with a positive SPW.

Limitations must be acknowledged. The sample size needed in order to obtain reliable estimates from logistic regression models relies on the number of events per variable. In this study, sample variance is increased in the final estimates, thus, the magnitude of the associations might be underestimated. Perhaps, the magnitude of the prediction of a positive SPW of SBP and PI could be higher, recalling the attention of trauma care teams at emergency departments to work actively when patients present with these characteristics.

Diagnosis of occult cardiac injury could be difficult. The clinical manifestation of penetrating cardiac injuries ranges from complete hemodynamic stability to acute cardiovascular collapse; therefore, early recognition is vital to successful management. ${ }^{6}$ Given the confined and nondistensible pericardial sac, tamponade adds significantly to the life-threatening risk of cardiac injury itself. In this study, clinical signs on admission of pericardial tamponade were significantly associated with increased odds of positive SPW, indicating that these could be the most important factor for the identification of occult cardiac injuries. Patients injured in the precordial region and presenting with any sign of pericardial tamponade could benefit from an immediate SPW procedure.

Patients with multiple penetrating injuries to the precordial region may present to the emergency department in extremis or in unstable condition. But, when they arrived in stable condition represent a significant diagnostic and therapeutic challenge. ${ }^{11}$ However, this study demonstrated that patients with single injuries to the precordial region or other anatomical location were associated with higher odds of positive SPW than patients with multiple injuries. Perhaps, patients with multiple injuries to the precordial region were taken to the OR for SPW because of increasing bias toward suspecting occult cardiac injuries. Nonetheless, these patients did not benefit from a SPW.

\section{CONCLUSION}

Systolic blood pressure and transient physiologic instability were not found as strong predictors of positive SPW. Emphasis on early recognition of signs of pericardial tamponade could be the most important factor for the identification of occult cardiac injuries. Patients with multiple injuries to the precordial region who reached the hospital may not benefit from a SPW. However, high level of awareness is important because the incidence of occult cardiac injuries is not negligible. In setting with low healthcare resources in which no other diagnostic tools are available, SPW continues to be a key diagnostic tool for occult cardiac injuries, in patients with penetrating injuries to the precordial region.

\section{REFERENCES}

1. Campbell NC, Thomson SR, Muckart DJ, et al. Review of 1198 cases of penetrating cardiac trauma. Br J Surg 1997;84:(12) 1737-1740.

2. Wall MJ, Tsai P, Mattox KL. Chapter 26. Heart and Thoracic Vascular Injuries. In: Mattox KL, Moore EE, Feliciano DV, eds. Trauma. New York, NY: McGraw-Hill; 2013.

3. Wall MJ Jr, Mattox KL, Chen CD, et al. Acute management of complex cardiac injuries. J Trauma 1997;42(5):905-912.

4. Ferrada R. Penetrating cardiac trauma. Panam J Trauma 2004;1(1):30-34.

5. Ball CG, Williams BH, Wyrzykowski AD, et al. A caveat to the performance of pericardial ultrasound in patients with penetrating cardiac wounds. J Trauma 2009;67(5):1123-1124.

6. Hommes M, Nicol AJ, van der Stok J, et al. Subxiphoid pericardial window to exclude occult cardiac injury after penetrating thoracoabdominal trauma. Br J Surg 2013; 100(11):1454-1458.

7. Sanchez AI, Villaveces A, Krafty RT, et al. Policies for alcohol restriction and their association with interpersonal violence: a time-series analysis of homicides in Cali, Colombia. Int J Epidemiol 2011;40(4):1037-1046. 
8. Advanced trauma life support (ATLS(R)): the 9th edition. J Trauma Acute Care Surg 2013;74:1363-1366.

9. Asensio JA, Mazzini FN, Perez-Alonso AJ, et al. Chapter 10. Subxiphoid pericardial window. In: Cioffi WG, Asensio JA, Adams CA, et al., editors. Atlas of Trauma/Emergency Surgical Techniques. Philadelphia, PA: Saunders, Elseiver Inc; 2014.
10. Ivatury RR, Nallathambi MN, Rohman M, et al. Penetrating cardiac trauma. Quantifying the severity of anatomic and physiologic injury. Ann Surg 1987;205(1):61-66.

11. Barden BE, Kent RB, 3rd. Multiple penetrating injuries to the heart diagnosed with ultrasonography. Southern Med J 2001;94(6):644-645. 


\section{INVITED COMMENTARY}

\section{Predictors of Positive Subxiphoid Pericardial Window in Stable Patients with Penetrating Injuries to the Precordial Region}

Historically, diagnostic subxiphoid pericardial window (SPW) was the gold standard for the diagnosis of patients with suspected hemopericardium due to traumatic penetrating injuries. In recent years, ultrasound (US) has replaced it as the method of choice to evaluate patients with a suspected cardiac injury after penetrating trauma. Cardiac ultrasound has a reported sensitivity of $100 \%$ and specificities in the range of 94.7 to $100 \% .^{1-6}$

In this paper, Sánchez et al state 'Subxiphoid pericardial window remains a valuable diagnostic tool for patients at risk of occult cardiac injuries'. They point out that US has several limitations to include: operator dependency, limited accuracy in the presence of associated hemothorax and limited availability in the setting of low healthcare resources. Due to these factors, the Authors contend that SPW continues to have a primary role in the diagnosis of penetrating cardiac injuries. The goal of their study was to identify the patients that could benefit from this procedure.

This is a prospective observational study conducted from 2000 to 2004 at an Urban Level I trauma center in Cali, Colombia. Patients with obvious cardiac injuries, presenting with hemorrhagic shock, pulseless electric activity or cardiac arrest were excluded from the study.

There were 287 patients with penetrating injuries (stab wounds vs gunshot wounds) to the precordial region. 104 patients met exclusion criteria and 183 patients were enrolled in the study and underwent SPW. Of these, 54.1\% suffered stab wounds and single injuries were observed in $78.7 \%$ of the patients. The median systolic blood pressure (SBP) on admission was $80 \mathrm{~mm} \mathrm{Hg}$ and $43.2 \%$ had a SBP $<80 \mathrm{~mm} \mathrm{Hg}$.

There were 41 positive SPW (22.4\%). The incidence of positive SPW was higher among stab wound (23.9\%) vs gunshot wounds $(14.3 \%)$ and this finding reached statistical significance.

The number of positive studies is fairly low and this implies that 142 patients or $77.4 \%$ of patients underwent a nontherapeutic and nondiagnostic SPW. One could argue that this low yield is justified in light of the reported low morbidity and mortality of SPW and the devastating consequences of a missed injury. The intent of this study is to attempt to identify factors that would help stratify the patients and increase the diagnostic and therapeutic yield of SPW in the setting where a cardiac ultrasound is unavailable due to lack of resources or lack of expertise.

On final analysis the sensitivity and specificity of SPW for the diagnosis of penetrating cardiac injury was 97.1 and $94.6 \%$. The positive and negative predictive values were 80.5 and $90.3 \%$, respectively.

The reliance on US has recently come under question in a recent article by Nicol et al published in Annals of Surgery. ${ }^{7}$ Nicol et al concluded that, 'the sensitivity of US to detect hemopericardium in stable patients was only $86.7 \%$, casting some doubt toward the reliability of US in the detection of occult cardiac injuries. The authors proposed an algorithm in which SPW was performed if the US was positive or equivocal.

Sanchez et al state that 183 of the patients were hemodynamically stable despite the fact that $43.2 \%$ of the patients had a SBP less than or equal to $80 \mathrm{~mm} \mathrm{Hg}$. The authors concluded, 'SBP and transient physiological instability were not found as strong predictors of positive SPW.' This may be due to their inclusion of conscious patients with SBP of $80 \mathrm{~mm} \mathrm{Hg}$ or less as hemodynamically stable. When considering hemodynamic stability in trauma the SBP value that is frequently referenced in the literature was $>90 \mathrm{~mm} \mathrm{Hg}$ and recent articles argue that this number should be $>110 \mathrm{~mm} \mathrm{Hg} .{ }^{8,9}$ The other concern is that half of the patients (53.2\%) presented with classical signs of pericardial tamponade. I am surprised that this number is not higher and would like to know what percent of positive patients had at least one clinical sign of cardiac tamponade. The majority of patients with cardiac tamponade do not present with all three components of Beck's triad or Kussmaul's sign. ${ }^{10,11}$

I concur with the author's conclusion that the diagnosis of occult cardiac injury can be difficult and early recognition is vital for successful management. Furthermore, evidence of cardiac tamponade is probably the most important factor for identification of occult cardiac injuries but several of the signs may be lacking. This can make the diagnosis more challenging but one should maintain a high index of suspicion with any precordial injury.

Patients with a single injury had a higher incident of positive SPW probably due to the fact that patients with multiple injuries were more likely to be taken directly to the Operating Room Theatre as they probably presented with obvious clinical signs of cardiac injuries and hence were excluded from this study.

Finally, I concur with the author's final recommendation that 'In setting with low healthcare resources in which no other diagnostic tools are available, SPW continues to be a key diagnostic tool for occult cardiac injuries'. In my 
opinion, the primary diagnostic tool in the setting of occult cardiac injury should be cardiac ultrasound. But, in the setting of limited resources or high clinical suspicion SPW still has an important role in appropriately trained hands.

The authors should be commended for their efforts to define the course of management of these complex patients and helping us understand that the management may be different in low resource centers were advanced technology or expertise with new technology may be lacking. As always, clinical judgment, high index of suspicion, making optimal use of all available resources and surgical expertise are the key determinants in the successful management of these patients.

Esteban Foianini MD Director, Clinica Foianini ATLS - Bolivia Santa Cruz de la Sierra, Bolivia

\section{Predictores de la ventana pericárdica en Positivo subxifoideo Los pacientes estables con lesiones penetrantes a la precordial}

Históricamente, la ventana pericárdica subxifoideo diagnóstica (VPS) se considera el estándar de oro para el diagnóstico en los pacientes con sospecha de hemopericardio secundario a lesiones traumáticas penetrantes. En los últimos años, la ecografía lo ha reemplazado como el método de elección para evaluar pacientes con la sospecha de tener una lesión cardiaca debido a un traumatismo penetrante. La ecocardiografía tiene una sensibilidad de $100 \%$ y especificidades en el intervalo de 94,7 a $100 \%$. 1-6

En este articulo, Sánchez et al indican que "La ventana pericárdica subxifoideo sigue siendo una herramienta diagnóstica valiosa en los pacientes que pueden tener lesiones cardíacas ocultas". Señalan que la ecografía tiene varias limitaciones que incluyen: su dependencia en el operador, precisión disminuida en presencia de un hemotórax asociado y la disponibilidad limitada en áreas con recursos de asistencia médicas austeras. Debido a estos factores, los autores sostienen que la VPS continúa teniendo un papel protagónico en el diagnóstico de lesiones cardiacas penetrantes. El objetivo de su estudio fue identificar los pacientes que podrían beneficiarse de este procedimiento.

Se trata de un estudio observacional prospectivo realizado desde el año 2000 hasta el 2004 en un Centro de Trauma Urbano de nivel I (clasificación Norteamericana que implica de mayor complejidad) en Cali, Colombia. Los pacientes con lesiones cardíacas evidentes, que ingresaron con shock hemorrágico, actividad eléctrica sin pulso o en paro cardíaco fueron excluidos del estudio.

Hubieron 287 pacientes con lesiones penetrantes (heridas de arma blanca versus heridas de balas) a la región precordial. 104 pacientes cumplieron con los criterios de exclusión y 183 pacientes fueron incluidos en el estudio y se les realizó una VPS. De estos, 54,1\% sufrieron una heridas por arma blanca y se observaron lesiones únicas en el 78,7\% de los pacientes. La media de la presión arterial sistólica al ingreso fue de $80 \mathrm{~mm} \mathrm{Hg} \mathrm{y} \mathrm{el} \mathrm{43,2 \%} \mathrm{tenían} \mathrm{una}$ presión arterial sistólica $<80 \mathrm{~mm} \mathrm{Hg}$.

Reportaron 41 VPS positivos (22,4\%). La incidencia de VPS positivo fue mayor entre los lesionados por arma blanca $(23,9 \%)$ versus heridas de bala $(14,3 \%)$ y este hallazgo fue estadísticamente significativo.

El número de estudios positivos es bastante bajo y esto implica que 142 pacientes o el 77,4\% de los pacientes fueron sometidos a una VPS no terapéutica o diagnóstica. Se podría argumentar que este bajo rendimiento se justifica en vista de la baja morbilidad y mortalidad reportada de la VPS y las devastadoras consecuencias de una lesión cardiaca no reconocida. La intención de este estudio es tratar de identificar los factores que podrían ayudar a estratificar a los pacientes y aumentar el rendimiento diagnóstico y terapéutico de la VPS en el entorno en el que una ecocardiografía no está disponible debido a la falta de recursos o la falta de experiencia.

En el análisis final, la sensibilidad y especificidad de VPS para el diagnóstico de la lesión cardiaca penetrante fue de 97.1 y 94,6\%. Los valores predictivos positivos y negativos fueron del 80,5 y 90,3\%, respectivamente.

La dependencia en la ecocardiografía ha sido cuestionado en un artículo reciente de Nicol et al publicado en Annals of Surgery.7 Nicol et al concluyeron que, "la sensibilidad de los ecocardiografía para detectar un hemopericardio en pacientes estables fue únicamente del 86,7\%", creando algunas dudas hacia la fiabilidad de la ecocardiografía en la detección de las lesiones cardíacas ocultas. Los autores propusieron un algoritmo en el cual se realiza la VPS si los ecocardiografía fuera positivo o dudoso.

Sánchez et al indican que 183 de los pacientes estaban hemodinamicamente estables a pesar del hecho de que el 43,2\% de los pacientes tenían una presión arterial sistólica menor o igual a 80mm Hg. Los autores concluyeron, 
" la presión arterial sistólica y la inestabilidad fisiológica transitoria no se ha encontrado como factores predictivos de una VPS positivo." Esta conclusión puede ser debido a la inclusión de pacientes conscientes con presión arterial sistólica de $80 \mathrm{~mm} \mathrm{Hg}$ o menos que fueron considerados como hemodinamicamente estable. Cuando consideramos la estabilidad hemodinámica en el trauma el valor de la presión arterial sistólica que se hace referencia con frecuencia en la literatura es $>90 \mathrm{~mm} \mathrm{Hg} \mathrm{y} \mathrm{artículos} \mathrm{recientes} \mathrm{argumentan} \mathrm{que} \mathrm{este} \mathrm{número} \mathrm{debe} \mathrm{ser} \mathrm{>} \mathrm{110mm} \mathrm{Hg.8,9} \mathrm{La} \mathrm{otra}$ preocupación es que la mitad de los pacientes (53,2\%) presentaron signos clásicos de taponamiento cardiaco. Me sorprende que este número no sea mayor y me gustaría saber qué porcentaje de pacientes positivos tenia al menos un signo clínico de taponamiento cardíaco. La mayoría de los pacientes con taponamiento cardíaco no presentan con los tres componentes de la tríada de Beck o el signo de Kussmaul. 10,11

Estoy de acuerdo con la conclusión del autor de que el diagnóstico de la lesión cardiaca oculta puede ser difícil y que la evaluación precoz es vital para el éxito del manejo. Adicionalmente, evidencia de un taponamiento cardíaco es probablemente el factor más importante para la identificación de las lesiones cardíacas ocultas pero varios de los signos pueden estar ausente. Esto puede hacer el diagnóstico más difícil, pero uno debe mantener un alto índice de sospecha con cualquier lesión precordial.

Los pacientes con una sola lesión tenían un mayor incidencia de tener una VPS positiva probablemente debido al hecho de que los pacientes con múltiples lesiones eran más propensos a ser llevado directamente a la sala de quirófanos, ya que probablemente presentaron con signos clínicos evidentes de lesiones cardíacas y por lo tanto fueron excluidos de este estudio.

Por último, estoy de acuerdo con la recomendación final del autor de que "En la situación donde los recursos sanitarios son escasos en los que no hay otras herramientas de diagnóstico disponibles, la VPS sigue siendo una herramienta de diagnóstico clave para las lesiones cardíacas ocultas '. En mi opinión, la primera herramienta de diagnóstico en la evaluación de la lesión cardiaca oculta debe ser una ecocardiografía. Pero, en el entorno de recursos limitados o alta sospecha clínica la VPS todavía tiene un rol importante en las manos de cirujanos adecuadamente formados.

Los autores deben ser elogiados por sus esfuerzos para definir el curso del manejo de estos pacientes complejos y en ayudarnos a comprender que el manejo puede ser distintos en los centros de escasos recursos donde tecnología de avanzada o experiencia con la nueva tecnología puede estar ausente. Como siempre, el criterio clínico, un alto índice de sospecha, haciendo uso óptimo de todos los recursos disponibles y la experiencia quirúrgica son los principales factores que determinan el éxito en el manejo de éstos pacientes.

Esteban Foianini MD

Director, Clinica Foianini

ATLS - Bolivia

Santa Cruz de la Sierra,

Bolivia 